\title{
RELIGIOUS FREEDOM AND THE IDEA OF ESTABLISHING ISLAMIC STATE
}

\author{
ABU HAPSIN ${ }^{1}$ \\ Universitas Islam Negeri Walisongo Semarang
}

\section{Abstract}

The idea of Gamwell on "religion as rational" was based on the concept that religious freedom is nothing other than a political discourse that can be figured out only through a democratic resolution. Changing paradigm from "religion as non-rational" to "religion as rational" is a necessary condition for entering a public debate. Yet, the sole public debate or public view is not enough to solve the modern political problematic. The public debate must be guided by a constitutional procedure affirmed by the body politic so that it fulfills the criteria of formal claim about justice. Applying qualitative research and literature review this research tried to reveal: Gamwell's idea of religious freedom, the features of the Islamic State as described by Abdul Rauf and Gamwell's concept of religious freedom and the idea of establishing the Islamic State advocated by Abdul Rauf.

Gagasan Gamwell tentang "agama itu rasional" didasarkan pada konsep bahwa kebebasan beragama tidak lain adalah wacana politik yang hanya bisa diraih melalui resolusi demokratis. Mengubah paradigma dari "agama sebagai tidak rasional" menjadi "agama sebagai rasional" adalah syarat yang diperlukan sebelum memasuki debat publik. Namun, debat publik atau pandangan publik saja tidak cukup untuk memecahkan masalah politik modern. Perdebatan publik harus dipandu oleh prosedur konstitusional yang ditegaskan oleh badan politik sehingga memenuhi kriteria klaim

Corresponding author; email: ${ }^{1}$ abu_hapsin@walisongo.ac.id

ISSN 0852-7172 (p) 2461-064X (e)

(C) 2017 Walisongo: Jurnal Penelitian Sosial Keagamaan

http://journal.walisongo.ac.id/index.php/walisongo 
formal tentang keadilan. Dengan menggunakan penelitian kualitatif dan kajian pustaka penelitian ini mencoba mengungkapkan: gagasan Gamwell tentang kebebasan beragama, ciri-ciri Negara Islam seperti yang dijelaskan oleh Abdul Rauf, dan konsep Gamwell tentang kebebasan beragama, serta gagasan untuk mendirikan Negara Islam yang dianjurkan oleh Abdul Rauf.

Keywords: Gamwell; religious freedom; Islamic state; democratic resolution.

\section{Introduction}

"There is no compulsion in religion; truly the right way has become clearly distinct from error; therefore, whoever disbelieves in the Shaitan and believes in Allah he indeed has laid hold on the firmest handle, which shall not break off, and Allah is Hearing, Knowing” (al-Quran, al-Baqarah: 256). ${ }^{2}$

The explanation of this verse stated that religion (din) here signifies the belief about God embodied in the above 'Verse of the Throne' and the entire system of life which rests upon it. The verse means that the system of Islam, embracing belief, morals and practical conduct cannot be imposed by compulsion. These are not things to which people can be yoked forcibly (Abdul-Rahman 2009).

The Muslim thinkers seem to agree unanimously that the above verse clearly and decisively indicates that Islam offers religious freedom, so that every time they discuss the concept of religious freedom, they always refer to that verse. Ibn Kathir, one of those scholars interpreted the above verse that meant for "not to force anyone to become Muslim, for Islam is plain and clear, and its proofs and evidence are plain and clear. Therefore, there is no need to force anyone to embrace Islam. Rather, whoever Allah directs to Islam, opens his heart for it and enlightens his

\footnotetext{
${ }^{2}$ This translation is quoted from (Asad 1980, 57)
} 
mind, will embrace Islam with certainty. Whoever Allah blinds his heart and seals his hearing and sight, then he will not benefit from being forced to embrace Islam (Abdul-Rahman, 2009)

One of the several contemporary Muslim thinkers who has tried to describe the concept of religious freedom in Islam and refers to the above verse is Tan Sri Muhammad Abdul Rauf. In his book, The Concept of Islamic State: with Particular Reference to Treatment of Non-Muslim Citizens (1988) he elaborates the features of the Islamic State and how it should treat the non-Muslim citizens. Apropos of the rights of the non-Muslims, especially that related to religious freedom, I find it very convincing and fair. This was clearly described and analyzed by Akram D. al-Umari in his article, Medinan Society at the Time of the Prophet (1991), in which stated how Muslims treated well the non-Muslim citizens.

However, no matter how just the treatment of the Islamic State in dealing with the non-Muslims would be, it raises at least two fundamental questions: what is the meaning of religious freedom? and, can the concept of religious freedom be defined only by one side, namely by the Muslims? I believe that the concept of religious freedom can only make sense in so far as it is defined or formulated by both sides, by the Muslims and the non-Muslims (Audi and Wolterstorff 1997). If Islam legitimates the plurality of religions as the above verse claims, logically the Islamic State should let the legitimate religious convictions define their own religious freedom.

In view of this, I would like to discuss whether the claim of religious freedom and the idea of establishing an Islamic State proposed by Abdul Rauf is a coherent political principle or not. In discussing his ideas, I would like to use the concept of religious freedom advocated by Franklin I. Gamwell in his work, The Meaning of Religious Freedom, Modern Politics and the 
Democratic Resolution (1995). This is based on the reason that, as far as I am concerned, this work offers a coherent resolution for figuring out the modern political problems related to religious freedom.

The discussion will be divided into three parts. The first part is that related to the Gamwell's idea of religious freedom. This will be used as the theoretical basis for analyzing the idea of establishing the Islamic State as proposed by Abdul Rauf. The second part will reiterate the features of the Islamic State as described by Abdul Rauf. The last part will discuss the application of Gamwell's concept of religious freedom and the idea of establishing the Islamic State advocated by Abdul Rauf.

\section{The Meaning of Religious Freedom}

Religious freedom and religious liberty are often used interchangeably. Both of them have a synonymous meaning, expressing the absence of coercion of someone mind in expressing his or her belief or conscience. Yet in the context of political and legal rights, the term "religious freedom" is more often used than the term "religious liberty" (Koshy 1992, 23; Attabani 1995).

Carilo de Albornoz, as quoted by Koshy, suggests that religious liberty or religious freedom has four main aspects, namely; liberty of conscience, liberty of religious expression, liberty of religious association and, the last, corporate and institutional religious freedom. Among these four aspects, freedom of conscience is the most genuine and an absolute right in the sense that inalienability transcends the other three aspects. Since the freedom of conscience is an absolute right, religious freedom should encompass freedom to choose or not to choose a certain religion. Personal truth must be regarded as the supreme value. It entails self-commitment and self-responsibility. It transgresses the commitment to other agents such as government and even 
god (Koshy 1992, 22). It is in this sense that Gamwell defines religion and only in this sense should the meaning of "authentic human being" be defined. Thus, in broader terms, religion is defined as a self commitment to personal truth since it is the foundation to determine the authenticity of a human being (Gamwell $1995,30-31) .^{3}$

The freedom of conscience constitutes the inner dimension, while the expression or the manifestation of the conscience, either manifested personally or institutionally, constitutes the external dimension of religious freedom (Koshy 1992, 24). The division of religious freedom into the internal and the external dimensions finally leads to an idea that the later is not absolute in nature. This means that the right to manifest the religious conscience is dependent on the other agents such as government and other elements of body politics. Even though for example, one's personal truth or personal conscience says that committing suicide is a noble act, he cannot manifest it freely by simply saying "this is my right". The manifestation of religious conscience is subject to public debate, discussion and assessment from the other agents. Thus, religious conscience or religious conviction is subject to public debate when it is manifested in a political arena. It is in this context that the idea of religious freedom is closely linked with politics.

According to Franklin I. Gamwell, the assessment of religious freedom in relation to politics can be described in two ways; religion as rational and religion as non-rational. The thesis of religion as rational suggests that every religious conviction is allowed to enter into a political arena. In a democratic dis-

${ }^{3}$ In the other parts of hisbook, Gamwell criticizes the idea of Sidney E. Mead because of his inclusive definition of religion. Mead defines religiononly that belongs to theistic religion. According to Gamwell, this is not sensible since this will eliminateother people's right to express his or her self-authenticity, see Gamwell $(1995,147)$. 
course, no one is allowed to proscribe other people to express their self-authenticity which is found in their religious conviction. But, as a consequence, the religious conviction must be ready to be debated and assessed publicly. This is why, he criticizes the political approaches which are based on the thesis of religion as non-rational like that developed by John Rawls, the approach of the partisans promoted by John C. Murray and the approach of the pluralist from Kent Greenawalt (1988). ${ }^{4}$ Gamwell is quite sure that the assessment of religion as non-rational will only end up with non-coherent resolution and will only produce non-coherent political principles. In brief, the assessment of religion as non-rational will not be able to solve what Gamwellcalls "the modern political problematic."

The modern political problematic refers to a condition in which religious authority loses its domination over the state and, at the same time, there is an increasing freedom to choose a given religious conviction within the political community. The erosion of the religious authority finally leads to the state to a legitimate plurality of religious convictions. The state can no more prescribe politically to limit the emergence of religious convictions. Thus, the modern political problems are characterized by an indeterminate number of religious convictions. The limitation of the number of religions can possibly be done only by force (Gamwell 1995, 5-10).

However, the limitation by force is not a good resolution since it does not run parallel with the idea of democracy. The democratic resolution to the modern political problems can work out only by letting the political community exercise their activities which is constituted or represented by their self-understanding. The self-understanding is, however, the choice of their

${ }^{4}$ To know how Gamwell criticizes the approaches which are based on the thesis of religion as non-rational, seeGamwell (1995, 47-115). 
purpose for the sake of searching and determining their self-authenticity as a human being (Gamwell 1995, 17).

Even though our activities choose and decide our purpose with understanding, "it does not mean that our understanding is always explicit (Gamwell 1995, 17)." This means that our purpose is not always chosen by our activities through a conscious thought. Since our activity is not always conscious and understands explicitly of all things completely, our activity also includes or is represented by "implicit understanding", that is the understanding which is excluded from conscious thought but it is so decisive that our explicit understanding dependent on it and without it our explicit understanding "could not be what it is" (Gamwell 1995, 17, 217).

Distinguishing the implicit understanding from the explicit understanding is important in order to know the formal distinction between religious and political activity.Since both religious and political activities are forms of human activities, both can only be differentiated from their explicit understanding, not from their implicit understanding (Gamwell 1995, 19). For example, a state stipulates the marital law which is based on the principle of monogamy. This activity is, of course, directed to answer explicitly the question about the state's policy, and hence, it is a political activity. But implicitly, it is religious activity since it implies that the state supports and implements the Christian understanding of the principle of marriage.

Because an understanding provides an answer to a given question, human activities are also distinguished by the question which is explicitly asked. Thus, religious activities are distinguished from political activities because of the question which is explicitly asked. On this account, Gamwell defines religion as "the primary form of culture in terms of which the comprehensive question is explicitly asked and answered. The 
term "form of culture" here means that a religion is "a set or system of concepts and symbols in terms of which human explicitly understand themselves" (Gamwell 1995, 23) while, the term "primary" indicates that there is also the secondary form of cultures such as theology, philosophy, and philosophical theology. If the "primary form" asks and answers to the comprehensive question explicitly and decisively, the "secondary form" asks and answers to the comprehensive question critically. Thus, theology and philosophy are forms of religious activity in order that the religious activity becomes self-critical (Gamwell 1995, 29). Meanwhile, the term "comprehensive" in the above definition refers to the purpose of life (Gamwell 1995, 18). Thus, the question about the religious activity might be formulated: what should the activities of the religion be or what should a religion do to fulfill the purpose of life?

If the religion asks and answers explicitly to the comprehensive question, the politics asks and answers explicitly to the question about the state. This is because the politics is only a form of association, not a form of culture. Hence, a political activity is not directed to ask and answer explicitly to the comprehensive question, but it is limited only to ask and answer explicitly to the question of the state. Therefore, the question about the political activity might be formulated: "what should the activities of the state be and what should the state do?" (Gamwell 1995, 32).

Based on the above explanation it is clear that our activity is constituted by both explicit and implicit self-understanding. If our activity is intended to understand the purpose of life, it is constituted by our "comprehensive self-understanding (Gamwell 1995, 18)." That is why, the question about the purpose of life should also be constituted by “comprehensive question", and it is the answer to the comprehensive question that the authenticity of a human being can be found(Gamwell 1995, 35-36). Since 
it is a religion that provides the comprehensive understanding and provides the answer to the comprehensive question, it is not wise to discard religion from the political arena. But, as a consequence, the religious conviction has to be ready to enter into a free and full public debate.

The above statements indicate that, for Gamwell, the religious conviction must be constituted in the political expression. But, before it becomes the state's policy, it must be tested through the public debate or public view. This public view is important for the sake of determining the validity of a given religious conviction. In view of this human experience and reason is, of course, very significant to see whether that religious conviction is valid or not (Gamwell 1995, 190). This idea is in line to what Mayer discussed related to the Islam and Human Rights Tradition and Politics (Mayer 1994, 173-76) in which she offers the concept of "Islamic human rights schemes" in the scheme of political way. These are the attempts done by conservative religious scholars and intellectuals to produce an Islamic version of human rights law-typically in the form of an Islamic "bill of rights". The schemes resulted sometimes replicate provisions found in documents like the 1948 Universal Declaration of $\mathrm{Hu}-$ man Rights. More often, however, they modify these provisions in accordance with Islamic criteria or introduce some alternative sets of rights which are not found in the contemporary international law. Mayer also offers to set up any discussion related to Islamic human rights.

The full and free debate is only possible to be done if we change our perspectives from the thesis of religion as non-rational to the thesis of religion as rational. This is the first and foremost step to be taken into consideration when we would like to follow Gamwell's ideas in overcoming the political problems related to religious freedom. It is a necessary condition for 
the following step proposed by him, namely "democratic resolution." Thus, before we come to a political arena, our mind should agree upon the idea that religious conviction is subject to public debate and discussion.

The democratic resolution of religious freedom entails a democratic constitution. The democratic constitution should encompass and answer both politically and religiously formulated problems. The formulation of the political problem will ask: is a given constitution consistent with the plurality of legitimate religions? In contrast, the formulation of the religious problem will ask: can a given constitution be affirmed by adherents of a plurality of religion (Gamwell 1995, 161). These two problematic formulations are of great significance for determining whether the public view or public debate can work out or not. A given constitution that does not encompass the answer to these two problematic formulations is not the democratic constitution, and hence, one without religious freedom.

The democratic constitution must also identify the participants in the discussion or debate and their rights in order that the discussion could be fully free. The procedure for making decisions, the procedure for executing decisions, the procedure for enforcing the prescription of the constitution, the procedure for adjudicating differences in relation to both decisions and the constitutional prescriptions must b included in the constitution. In order to be a fully free-debate, the constitution itself must be subject to continual assessment. Thus, the procedure for changing or amending the constitution must be explicitly stated in the constitution (Gamwell 1995, 163). In brief, the democratic constitution should reflect the affirmation of all religious adherents. That is why the constitution that explicitly describes a certain comprehensive understanding is not a democratic constitution. The democratic constitution must be neutral from any explicit 
claim of any comprehensive understanding.

The democratic decision produced by the democratic constitution might not be in line with other comprehensive understandings or does not satisfy the other religious adherents. But insofar as the procedure reflects justice, in the sense that that procedure has been stipulated trough agreement before the decision emerges, there is no reason for the other adherents of religion not to obey that decision. In other words, they might be in disagreement with that decision, but they have to obey and respect it as long as it is stipulated through an agreed procedure. The inconsistency to the democratic procedure means inconsistency to the overriding commitment and inconsistency to the idea of religious freedom itself (Gamwell 1995, 164-67).

The feeling or the stance that a given constitution is just might change from time to time. A given religious adherent might feel that the decision making procedure written explicitly in the constitution is just and, therefore, they are bound to a commitment to it. But, later, after undertaking a series of debates, they find the decision-making procedure unjust. As a result, they want to change their previous commitment. It is very relevant to mention the research result of Charles $\mathrm{M}$. North and Carl R. Gwin (2004, 103-17) that was done in 59 countries and revealed that the establishment of state religion and constitutional protection of religion had a very significant opposing effect. The existence of a state religion reduces attendance of religious practices, whereas each decade of constitutional protection increase attendance of religious practice significantly. It was also found that other measures of religious regulation have a negative effect on attendance. Besides that, it was found also that ironically the motive behind the establishment of a particular state religion is to strengthen that religion, but the effects are ultimately undermine the vitality of the established religion. 
The democratic discourse, however, does not regard changing commitment as an aberration of the commitment itself. Changing commitment to the overriding decisions is justifiable. Those who disagree must have a room in the constitution in order to persuade the body politic, say the other religious adherents, that a certain decision-making procedure written in the constitution must be changed. While they have the opportunity to persuade the other religious adherents to change their commitment to the overriding decisions, at the same time they have to respect and comply with the decisions produced through that decision-making procedure with which they now disagree (Gamwell 1995, 167).

With the above description, Gamwell stresses a distinction between formal and material claims about justice. The formal justice is a justice which is reflected by and manifested in the constitutional procedure that overrides the other decisions. As long as that overriding constitutional procedure is affirmed by the body politics, there has been the claim about justice. Thus, the affirmation of the body politic to the overriding constitutional procedure is a decisive factor to determine that the formal claim about justice has been fulfilled. While the material justice is a justice which is manifested in the decisions which are produced through the constitutional procedure.

In the democratic discourse, what has been at stake is the formal claim about justice. The material claim about justice might be different from one to another adherent of various religious convictions. But, as long as the formal claim about justice manifested in the procedure of making, executing, enforcing and changing decisions is affirmed by the adherents of all religious convictions the democratic discourse can work out (Gamwell 1995). Thus, even though the material claim about justice manifested in, for instance, a given ordinance cannot satisfy the 
whole body politic, all must obey that ordinance since it is stipulated through the overriding constitutional procedure that has fulfilled the criteria of the formal claim of justice. This is what has made Gamwell quite sure that the democratic resolution is the only way to solve the modern political problems related to religious freedom. The full and free debate is a coherent constitutional principle which is able to unite a political community through a formal claim about justice (Gamwell 1995, 183).

Although the democratic constitution emphasizes the importance of the procedural justice or formal claim about justice, this does not mean that the material justice can be neglected. The material claim about justice manifested in a given ordinance must also be tested. In other words, the comprehensive understanding or the religious conviction that now becomes an ordinance must be validated by appealing to human experience and reason (Gamwell 1995, 190). For instance, the body politic stipulates an ordinance allowing the practice of slavery. The ordinance is, finally, stipulated through voting after having been debated freely and in accord with the affirmed constitutional procedure or procedural justice. Although this ordinance is stipulated through the procedural justice, it is not in line with the idea of democratic discourse since human reason and experience says that practicing slavery is inhuman. Thus, a religious conviction which is represented in the ordinance contradicts the idea of religious freedom. This ordinance implicitly indicates that there is no religious freedom.

From the above explanation, it is clear that the democratic resolution entails the involvement of various legitimate comprehensive understandings or various religious convictions to the play in a political arena. As a result, the democratic resolution of religious freedom as proposed by Gamwell can work out only if we change our paradigm from the thesis of "religion as non-ra- 
tional" to the thesis of "religion as rational". The term "religion as rational" here means that every religious conviction must be ready to be freely and fully debated.

Changing paradigm from the thesis of religion as non-rational to religion as rational is a very significant precondition without which there would be no democratic discourse. However, the only public view or public debate is not enough to settle the modern political problems related to religious freedom. The public debate must be guided by a democratic constitution in order that the public debate could produce a democratic decision.

The democratic constitution must fulfill the criteria of the formal claim about justice, that is a constitutional procedure that has had the affirmation of the body politic. So important is the affirmed constitutional procedure that there would be no democratic discourse without it. Yet, the sole just constitutional procedure is not enough unless the decisions produced through that constitutional procedure also fulfill the criteria of the material claim about justice.

\section{The Features of the Islamic State}

The following discussion will describe the features of the Islamic State as proposed by Abdul Rauf in his book The Concept of Islamic State; with Particular Reference to Treatment of Non-Muslim Citizens (1988). Since his description is not wholly related to the concept of religious freedom advocated by Franklin I. Gamwell, I will discuss only four features: sovereignty, shura or the consultative body, human equality and adherence to sharia or Islamic law.

Abdul Rauf believes that in the Islamic State, the loyalty and sovereignty belong to Allah. He criticizes modern political ideas, stating that in them, loyalty should be addressed to territorial entity and sovereignty is in the hand of the people. This is differ- 
ent from the Islamic State where the House of Representatives does not have an absolute and independent power, in the sense that it must always seek the revealed guidance, namely the $\mathrm{Qu}$ ran and the Prophetic Tradition (Abdul Rauf 1988, 22).

Under the Islamic political system, the rulers should rule on behalf of Allah. This resembles what has been done by the Prophet Muhammad (peace be upon him). The main duty of the rulers is executing what Allah has commanded. If there is a gap between the rulers and the House of Representatives, all have to seek the guidance from the sharia (Abdul Rauf 1988, 22).

Since the loyalty and sovereignty belong to Allah, there is no room for nationality in Islam. Nationalism is justifiable only insofar as it is intended to mobilize the people to resist foreign domination (Abdul Rauf 1988, 22).

The second feature of the Islamic State which is closely related to the idea of religious freedom is that about Shura or the Consultative body. The Shura institution had long been the practice of the Muslim rulers from the time of the Prophet to the time of Ali, the fourth successor of the Prophet. The Shura terminated when the political system changed from Caliphate to dynasty system (Abdul Rauf 1988, 25-29).

Even though the practice of mutual consultation in the early periods of Islam was conducted in a simple and natural way, this concept has laid down a good foundation for the sake of creating parliamentary as well as check and balance system as practiced in the modern political system. In the decision-making process, the first step to be done is mutual consultation. But if the member of Uli al-Amri (People Assembly) are in disagreement, the opinion of the majority should be binding even though this opinion might not in line with the wisdom of the chief executive. Yet, to some extent, the chief executive still has the right to veto (Abdul Rauf 1988, 30-31). 
The third feature of the Islamic State which is closely related to the concept of religious freedom is the commitment to sharia. In its broader sense, sharia means the total guidance derived from the Quran and from the model of the Prophet Muhammad. On this account, the sharia covers regulation of all aspects of a human being either it is formulated in Islamic Theology, Islamic Ethics, Islamic Law or the other branches of Islamic science. However, in its narrow sense, sharia is always identified with Islamic Law (Abdul Rauf 1988, 38).

The fourth feature of the Islamic State is that related to the concept of equality of human being. The Islamic State respects the principle of human equality for all citizens. Both Muslim and non-Muslim have an equal blood price. This is why, as the Quran stipulates, if a Muslim kills a non-Muslim, the Muslim is liable to the death penalty. In brief, in the Islamic State, no class or group of society has the right to special treatment. All of the society "enjoy the equal right and equal opportunity (Abdul Rauf 1988, 36-37).”

In legal cases, criminal and civil cases, all citizens, regardless of their religious background, have to be treated equally. The blood and the wealth of the non-Muslim must be protected the same as the blood and the wealth of the Muslim citizen. The non-Muslims have the right to take part in the state services, such as health, education, and economy (Abdul Rauf 1988, 5759). In other words, like the Muslim citizen, the non-Muslim citizen has to be trusted to hold public offices and to serve in the military as long as they are qualified. The non-Muslim citizen must not suffer from any discrimination, except holding the position with religious nature, such as the Mufti (jurist consult) and the Imam or the leader of a religious congregation (Abdul Rauf 1988, 55; Rahman 1985; Sisk 1992).

In the Islamic State the non-Muslims have the right to per- 
form or to practice their religious convictions as long as doing so does not cause serious harm to others in the community. They are not obliged to observe the prohibitions which are peculiar to Muslim, such as consuming fork and wine insofar as this does not invite serious harm to public security. However, the practice of usury, even if the non-Muslim believes it to be lawful, must be forbidden since this practice can elicit a bad influence on the whole society and on the economic condition in general (Abdul Rauf 1988, 50-51).

\section{Religious Freedom and Islamic State: Gamwellian Approach}

In the previous section, I have reiterated the features of the Islamic State proposed by Abdul Rauf. I choose only four out of six features promoted by him since the other two features can be explicitly included in those four features. The features of political authority and the principle of justice can be included in the features of sovereignty and human equality.

Actually, the term "Islamic State" itself indicates that the state explicitly supports Islam as the answer to the comprehensive question. According to Gamwell, this explicit support is, of course, not justifiable since it will eliminate the free and full public debate or public view (Gamwell 1995, 167, 186). That is why, as long as a state mentions the word "Islamic" explicitly, like the Islamic Republic of Pakistan or The Islamic Republic of Iran, the free and full debate as proposed by Gamwell cannot work out. Consequently, it is impossible to manifest the democratic discourse.

Stating the word "Islamic" in the constitution, however, will have a great impact on other decisions. A constitution is a procedure that overrides the other decisions. In the democratic discourse, it is not justifiable to eliminate the rights of the other adherents of different religious convictions to take part in the 
public debate. The explicit statement of the Word "Islamic" in the constitution, however, will eliminate the rights of the other religious adherents to express their religious convictions. This is, of course, not in line with the democratic discourse because eliminating the right to express a given religious conviction means eliminating the right to express self-authenticity. In view of this, a question emerges, can a state be named "Islamic State" without mentioning it explicitly in its constitution? If the answer is "no," it means that, according to Gamwellian approach, there is no religious freedom.

A similar question can be posed in relation to the concept of sovereignty. Can an Islamic State put an article in its constitution stating that the sovereignty shall be in the hand of the people? An explicit statement about "Allah's Sovereignty" in the constitution, however, will blur our vision in distinguishing the meaning of political activity and religious activity. Both become indistinct. As stated in section two, political activity is addressed to ask and answer explicitly to the question of the state, while religious activity is directed to ask and answer explicitly to the comprehensive question. Thus, if the words "Allah's sovereignty" is written explicitly in a constitution, that constitution no more reflects a political activity. In order for the constitution to reflect the political activity, that constitution must explicitly state that the sovereignty shall be in the hand of the people. Also, the explicit statement about "Allah's Sovereignty" means that the state affirms and endorse explicitly a given comprehensive conviction, namely the conviction of the people who believe in Allah.

In the democratic discourse, the state cannot explicitly support any answer to the comprehensive question. But this does not mean that the state eliminates the role of religion in political life. In the democratic discourse, the religious essential to the 
body politic in the sense that every political decision should implicitly represent a valid comprehensive conviction. Whatis not in line with the democratic discourse is the "explicit" endorsement of the state to a given comprehensive conviction (Gamwell 1995, 205). This is why, as far as the words "Islamic" and "Allah's Sovereignty" is explicitly stated in the constitution there would be no religious freedom.

Suppose the articles which explicitly stated, "Allah's sovereignty" and "Islamic State" in the constitution is the amendments produced through an overriding constitutional decision. The question here is, what kind of overriding constitutional decision or procedure can be used as a reference to produce these amendments?

A democratic constitution, however, must eliminate any explicit supporter explicit affirmation to any comprehensive conviction (Gamwell 1995, 167, 186). Thus the overriding constitutional procedure is possibly formulated: "the state shall not explicitly support or affirm any religious conviction." If this is the overriding constitutional procedure, then, how can these amendments be produced? If the above overriding constitutional procedure is affirmed by the body politic, while at the same time there are some decisions, say articles, about "Allah's sovereignty" and "Islamic State" in the constitution, the constitution must be self-contradictory.

The other features of the Islamic State that need further discussion are those related to the concept of Shura (Consultative Body) and human equality. As far as I know, Abdul Rauf does not elaborate the criteria for the membership of the Shura. Who can be the member of the Shura and how decision-making process should be done are not explained.

According to the democratic discourse, the member of the Consultative Body must not be limited only to one or some ad- 
herent of religious conviction. This is the logical consequence of the idea that every citizen is free to express his or her own religious conviction which is believed to provide his or her authenticity as a human being. That is why there is no reason not to accommodate their aspiration in the Consultative Body.

The way in which their aspiration is accommodated could be deferent from one to another country. In a more populated country, one member of the Consultative Body might represent many more constituents than he or she might do in a less populated country. This procedure must be clear and must be stated explicitly in the constitution and must get the affirmation of the body politic. This constitutional procedure must give a room for the whole adherents of different religious convictions. The question of whether a given religious adherent can utilize that room or not is another thing. The most important thing is that the constitution must fulfill the requirement of what Gamwell call "formal claim about justice," in the sense that the whole body politic, regardless of their different religious convictions, must affirm the constitutional procedure that overrides any decision (Gamwell 1995, 175).

With the above explanation, I would argue that there would not be religious freedom in a country whose Consultative Body member is limited only to the adherents of a given religious conviction. Now, the question is, can an Islamic State provide a constitutional procedure that includes the whole body politic to have the same rights and opportunity to sit in the Shura (Consultative Body)? If the answer is "no," it means that there is no religious freedom. Thus, even though Abdul Rauf claims that the non-Muslim citizen has a full religious freedom (Abdul Rauf 1988, 45-51), as far as that procedure is not stated clearly and explicitly in the constitution, according to Gamwell, there is no religious freedom. 
As stated in section two, in the democratic discourse, the formal claim about justice which is constituted in the constitutional procedure is primary. This is why Gamwell believes that religious freedom as modern political problems is nothing other than a constitutional matter (Gamwell 1995, 37). Because the democratic resolution to the modern political problems emphasizes primarily on the constitutional procedure, consequently defining religious freedom and its ramifications such as the right to express and to manifest the religious conviction, the rights to sit in the Shura (Consultative Body) and the rights to sit in any political position cannot be dependent only on a given religious conviction. Thus, even though, for instance, the Muslims constitute the majority, the concept of religious freedom must be defined by the Muslims and the non-Muslims as well. Also, this concept must be written clearly and explicitly in the constitution and must get the affirmation of the whole adherents of different religious convictions in order to fulfill the formal claim about justice (Fox 2008).

Even though in the democratic discourse, the formal claims about justice or the constitutional procedure is primary, this does not mean that the material claim about justice which is constituted in every decision can be neglected. Human reason and experience, however, will judge whether the decision produced through the overriding constitutional procedure is just or not. In other words, the human reason and experience shall be the criteria in order to measure the material claims about justice. On this account, the treatment of an Islamic State, as well as the concept of religious freedom offered by Abdul Rauf, is, of course, very convincing and beautiful (Abdul Rauf 1988, 45-51). Whoever reads these concepts will come to a conclusion that the Islamic State does fulfill the material claim about justice.

However, for Gamwell, no matter how convincing and 
beautiful these concepts are, there would be no religious freedom insofar as there is no full and free debate. This full and free debate can, of course, be done if only there is a procedural guarantee which is clearly and explicitly stated in a constitutional procedure. Thus, the guarantee of material claims about justice as described by Abdul Rauf will be meaningless unless it is accompanied by the procedural guarantee. In the democratic discourse, to repeat what I have stated, fulfilling the formal claim about justice is more important than fulfilling the material claim about justice.

The last feature is that the Islamic State must have a deep commitment to the dictates of sharia (Abdul Rauf 1988, 38). Again, in the democratic discourse, the state is proscribed to "support the teaching of any religion or answer to the comprehensive question"(Gamwell 1995, 167, 186). This does not mean that the state prohibits the adherents of Islam from having a deep commitment to the sharia. In the democratic discourse, sharia, which constitutes the answer to the comprehensive question, is essential to the Muslims. What is not in line with the democratic discourse is the explicit endorsement of the state to the sharia. Thus, the allegiance of the state to a given religious conviction and regards it as the state's explicit answer to the comprehensive question is unjustifiable (Gamwell 1995, 205).

In practice, the state might accept the capital punishment from the sharia, say Islam, but might reject its principle of relative polygamy. Instead, the state might accept the idea of absolute monogamy believed by the Christian. Or, after being freely and fully debated through a just and affirmed constitutional procedure, the Shariah might become personal and criminal law. But, if the state accepts the sharia as the criminal and personal law, it is simply because the body politic agrees on it, not because of the desire of the state to co-opt Islamic ideas and make 
it as the answer to the comprehensive question. The political activity, however, is not intended to ask and answer explicitly the comprehensive question. Thus, as far as the criminal and personal law which is derived from the sharia is stipulated through an affirmed constitutional procedure, there is no reason for the other religious adherents not to obey these laws insofar as both laws are not against human reason and experience.

In the debate, let us say parliamentary debate, every religious adherent free to refer to their comprehensive understanding or religious convictions. The Muslims are allowed to refer to their sharia, similarly, the Christians are allowed to refer to their canonical book as a reference, the Buddhists are justifiable to base their argument on Tri Pitaka and the a-theist groups can use their personal truth to buttress their argument. In brief, every religious adherent of a religious conviction is free to use his or her religious conviction as a reference as well as the basis for argument (Gill 2007). This is different from the idea of free-standing justice of John Rawls which requires justification only from the ideas that are implicit in the political culture (Rawls 2005, 10). Hence, no religious conviction is important to politics. Religious conviction should be left behind when we play in the political arena.

Even though the sharia has been the main element of the state's political activities, the state must maintain its neutrality toward the sharia. The state cannot claim the sharia to be its comprehensive understanding of the comprehensive question. When the sharia has been the main element of the state's political activity, its function changes. The sharia which was formerly regarded as the answer to the comprehensive question now has been the state's political activity. Because the political activity is not intended to provide the answer to the comprehensive question, whatever the decision derived from the sharia must not be 
addressed to answer the comprehensive question.

From the above explanation, its clear that Gamwellian approach on religious freedom requires the neutrality of the state to support explicitly to a given religious conviction, including the sharia. In view of this, the question emerges, can a state be named "Islamic State" without mentioning explicitly about its commitment to the sharia as that proposed by Abdul Rauf? If the answer is "no", there would be no full and free debate, and, without full and free debate, there would be no democratic discourse, and, the absence of the democratic discourse means the absence religious freedom.

\section{Conclusion}

Gamwell believes that religious freedom is nothing other than a political discourse that can figure out only through a democratic resolution. According to the democratic resolution, it is justifiable to bring a given religious conviction into the political arena because it is the religious conviction that provides the answer to the comprehensive question, and it is the answer to the comprehensive question that the authenticity of a human being can be found. Because the authenticity of a human being cannot be fragmented, it is necessary that the religious conviction is involved in the political arena. As a result, the religious conviction should be ready to be freely and fully debated. This is what Gamwell means with "religion as rational."

Changing paradigm from "religion as non-rational" to "religion as rational" is a necessary condition for entering a public debate. Yet, the sole public debate or public view is not enough to solve the modern political problems. The public debate must be guided by a constitutional procedure affirmed by the body politic so that it fulfills the criteria of formal claim about justice. So important is the affirmed constitutional procedure in 
the democratic discourse that Gamwell believes that religious freedom is nothing other than constitutional matter.

Because the modern political problem of religious freedom is a constitutional matter, the idea of establishing the Islamic State proposed by Abdul Rauf elicits at least four important questions. First, can a state be named "Islamic State" without mentioning the word "Islamic" in its constitution? Second, can a state be named "Islamic State" without mentioning explicitly the words "sovereignty belongs to Allah" in its constitution? Third, Can a state be named "Islamic State" without mentioning explicitly about its commitment to sharia in its constitution? Fourth, can a state be named "Islamic State" whose constitution states explicitly that all adherents of different religious convictions have the equal opportunity and rights for any political position, including the position of the head of the state? If the answer of these four question is "yes", it means that there is religious freedom. On the contrary, if the answer is "no", it means that there is no religious freedom.

Another logical consequence of the dictum that "religious freedom is constitutional matter" is that the affirmation of the whole body politic is of a great significance to determine whether or not a given constitutional procedure is just. Since the "affirmation" of the body politic is a determinant, the formulation of the constitutional procedure related to religious freedom cannot be formulated only by the Muslims, even if they are the majority. This formulation requires the involvement of the body politic without regard to their different religious conviction. This is why, even though Abdul Rauf claims that, in an Islamic State, the non-Muslims will have a just treatment and will have the rights to religious freedom, it will be meaningless unless these guarantees are explicitly stated in the constitution. 


\section{Bibliography}

Abdul-Rahman, Muhammad Saed. 2009. Tafsir Ibn Kathir Juz' 3 (Part 3): Al-Baqarah 253 To Al-I-'Imran 92. 2nd ed. London: MSA Publication Ltd.

Abdul Rauf, Tan Sri Muhammad. 1988. The Concept of Islamic State; With Particular Reference to Treatment of Non-Muslim Citizens. Malaysia: Islamic Affairs Division Prime Minister's Department.

Al-'Umari, Akram Diya'. 1991. Madinan Society at the Time of the Prophet Vol I. Virginia: International Institute of Islamic Thought.

Asad, Muhammad. 1980. The Message of the Quran. Lahore: Maktaba Jawahar ul-Uloom.

Attabani, Ghazi Salahuddin. 1995. "Islamic Syari'ah and the Status of Non Muslim." In Religion, Law and Society, edited by Tarek Mitri. Geneva: World Council Churches.

Audi, Robert, and Nicholas Wolterstorff. 1997. Religion in the Public Square: The Place of Religious Convictions in Political Debate. Boston: Rowman \& Littlefield Publishers.

Fox, Jonathan. 2008. A World Survey of Religion and the State. Cambridge: Cambridge University Press.

Gamwell, Franklin I. 1995. The Meaning of Religious Freedom: Modern Politics and the Democratic Resolution. New York: State University of New York Press.

Gill, Anthony James. 2007. The Political Origins of Religious Liberty. Cambridge: Cambridge University Press.

Greenawalt, Kent. 1988. Religious Convictions and Political Choice. New York: Oxford University Press. 
Koshy, Ninan. 1992. Religious Freedom in a Changing World / Ninan Koshy. - Version Details - Trove. Geneva: World Council of Churches Publications.

Mayer, Ann Elizabeth. 1994. "Universal Versus Islamic Human Rights: A Clash of Cultures or a Clash with a Construct?" Michigan Journal of International Law 15 (2). University of Michigan Law School.

North, Charles M, and Carl M. Gwin. 2004. "Religious Freedom and Unintended Consequences of State Religion." Southern Economic Journal 71 (1): 103-17.

Rahman, Fazlur. 1985. "Laws and Ethics in Islam.” In Ethics in Islam, edited by Richard G. Van Hovanism. Malibu: Udena Publication.

Rawls, John. 2005. Political Liberalism. New York: Columbia University Press.

Sisk, Timothy D. 1992. Islam and Democracy; Religion Politics and Power in the Middle East. Washington D.C.: United States Institutes of Peace Press. 
This page intentionally left blank 